\title{
Interference proceedings and innovation goals of the CRISPR-Cas9 patent
}

\section{Sunita Tripathy*}

The United States' Patent Trial and Appeal Board (PTAB), formerly US Patent and Trademark Office's Board of Patent Appeals and Interferences (BPAI), ${ }^{1}$ decided a highly contested interference proceeding concerning the Type-II CRISPR-Cas9 gene editing technology in February 2017. ${ }^{2}$ Clustered regularly interspaced short palindromic repeats (CRISPR) has been hailed as one of the most important innovations of bioscience in the 21 st century. ${ }^{3}$ It allows scientists to edit gene sequences in an effective manner, akin to a word processor. This is a sharp improvement from preexisting methods like Transcription Activator-Like Effector Nucleases (TALENs) and Zinc-Finger Nucleases (ZFNs) in biological research. ${ }^{4}$

CRISPR is an adaptive immune process first noticed in bacteria. Jennifer Doudna, of the University of California, and Emmanuelle Charpentier, now at the Max Planck Institute for Infection Biology, published an article in 2012 demonstrating the use of this process to edit genome sequences in vitro ('Jinek 2012). ${ }^{5}$ By delivering a synthetic RNA protein, the CRISPR-Cas9 enzyme could be guided to a specific gene site. The process enabled them to remove specific genes or add new ones and change the genetic sequencing. Doudna and Charpentier filed for a patent before the USPTO in March 2013.

In December 2012, Dr Feng Zhang of the Broad Institute, affiliated with MIT and Harvard, filed for a patent for the use of CRISPR specifically in eukaryotic cells under an expedited procedure. Within 6 months, the Broad patent was granted while the one filed by University of California remained pending even though it was filed first. Eventually, the University of California petitioned for an interference proceeding before the PTAB. The interference was decided in favor of the Broad Institute and an appeal challenging it is pending for disposal at the US Court of Appeals for the Federal Circuit. ${ }^{6}$

\footnotetext{
Email: stripathy@jgu.edu.in. The author is thankful for the discussions with Dr Malathi Lakshmikumaran of Lakshmikumaran \& Sridharan Attorneys and Dr Shubha Ghosh of Syracuse University College of Law on the subject matter. She also acknowledges with thanks the research assistance of her student Asmita Singhvi.

1 Reform under the Leahy-Smith America Invents Act, 2011 effective 16 September 2012.

2 Broad Inst, Inc $v$ Regents of Univ Cal, No 106,048, 2017 WL 657415 (PTAB, 15 February 2017).
}

\section{The author}

- Sunita Tripathy is Associate Professor, Jindal Global Law School (JGLS), O.P Jindal Global University in Haryana, India.

\section{This article}

- This article critically analyses one of the last interference proceedings before the United States Patent and Trademark Office (USPTO) since the America Invents Act (AIA) was passed. It examines the interference proceeding between University of California, Berkeley and the Broad Institute for the patent on the use of the Clustered regularly interspaced short palindromic repeats (CRISPR) gene editing system, which was terminated by the Patent Trial and Appeal Board (PTAB) in February 2017. The aim is to review the 'obviousness standard' in US patent law and question whether, once the basics of a technique are well known, the application of the technology in different contexts becomes obvious too? How should inventorship be decided in such cases?

- PTAB's determination on what is meant by the 'reasonable expectation of success' in using the technology in a different context while establishing inventorship is examined to address the questions. The analysis is further complimented with an explanation of the procedural changes since the transition to a first-inventor-to-file system, effective since 2013 . The possible advantages of the new policy reform that abolished interference proceedings to prominently adopt new derivation proceedings in priority claims are elaborated upon.

- Finally, it is inferred that the practical consequences of this long-drawn patent battle do not bode well for technological innovation and scientific research, hence newer methods for developing, managing, transferring and commercializing this path-breaking scientific advancement is needed. Efforts to create a worldwide licensing pool of CRISPR patents has great promise and will need to be studied closely as a parallel measure that may offer a winwin in terms of innovation goals for all concerned.

A critical analysis of the interference proceeding between University of California, Berkeley (UC) and the Broad Institute (Broad) for the patent on the use of

3 Jennifer Doudna and Samuel Sternberg, A Crack In Creation: Gene Editing And The Unthinkable Power To Control Evolution (Barnes \& Noble 2017) 117-18.

4 TALENs and ZFNs are referred to as chimeric nucleases.

5 Martin Jinek and others, 'A Programmable Dual-RNA-Guided DNA Endonuclease In Adaptive Bacterial Immunity’ (2012) 337 Science 816.

6 Regents of Univ Cal v Broad Inst, Inc, No 17-1907 (Fed Cir, 25 July 2017). 
CRISPR gene editing system is presented here. The article briefly reviews the US law on interference proceedings and related case law. It then discusses the practical consequences of this long-drawn patent battle and reflects on suitable solutions to meet the innovation goals of this groundbreaking scientific advancement. Finally, the article underlines the importance of developing a just procedure for establishing inventorship.

Broad began by posing an extremely important challenge to the PTAB. It argued that an essential pre-condition-interference-in-fact which is a threshold requirement as per 37 CFR section 41.203 (a) —was not fulfilled in this case; hence the proceeding was not maintainable. The PTAB had to determine whether UC's patent application regarding the use of CRISPR in an in vitro environment as prior art renders its use in a eukaryotic environment obvious. Answering in the negative, the PTAB ruled that there was no interference-infact. Thus, the interference should not have been declared in the first place.

\section{Legal context}

\section{The shift from first-to-invent to first-inventor-to-file}

US patent law was, until recently, significantly distinct from other legal systems. Before the Leahy-Smith America Invents Act of 2011 (AIA), USPTO granted patents on a first-to-invent basis. This system was characterized by detailed legal mechanisms for determining priority, including complex technical interference proceedings. ${ }^{7}$ It necessitated means for establishing the date at which an invention was first conceived, often including detailed log-book entries meticulously signed and dated by the inventor and countersigned by a third party to prove inventorship. ${ }^{8}$ AIA ushered in a host of changes to this system the most significant of which was the adoption of the 'first inventor-to-file system'. This transition required that, for all patent applications with an effective filing date after 15 March 2013, interference proceedings be abolished. In their place, derivation proceedings ${ }^{9}$ were introduced: these retain only some elements of the interference proceedings and are

7 Josh Lerner and others, 'Leahy-Smith America Invents Act: Preliminary Small Business Impacts', June 2015, SBA Advocacy.

8 Dennis Crouch, 'First to File versus First Inventor to File', 11 December 2009, PatentlyO < https://patentlyo.com/patent/2009/12/first-to-file-ver sus-first-inventor-to-file.html> accessed 26 June 2018.

9 See $<$ https://www.uspto.gov/patents-application-process/appealing-pat ent-decisions/trials/derivation-proceeding > accessed 26 June 2018.

10 Janelle Waack, 'Interference Proceedings in Post-AIA America', 14 February $2012<$ http://www.insidecounsel.com/2012/02/14/ip-interfer ence-proceedings-in-post-aia-america?slreturn $=1489693725>$ accessed 26 June 2018. conducted in a manner similar to inter partes reviews. ${ }^{10}$ Thus, as a matter of procedure, petitioners challenging the validity of any US patent filed after this date are now required to demonstrate a reasonable likelihood that their patent would prevail in a dispute before the USPTO.

The CRISPR-Cas 9 case is one of the last interference proceedings in US history. Therefore, a complete understanding of the tediousness of the process will pave the way for greater deliberation and clarity on the derivation standards that should be adopted under AIA.

\section{Interference proceedings}

When the subject matter of two or more pending patent applications or of a pending patent application and an unexpired patent appears to be substantially same, the first inventor is determined through interference proceedings. ${ }^{11}$ Effectively, interference is an inter partes review which results in a winner-take-all situation. ${ }^{12}$ The basis of these proceedings is USC section 135 and they are governed by 37CFR sections 41.200-41.208. In practical terms, interference proceedings were rare especially due to the high costs involved. ${ }^{13}$ In case of success, the affected party is given a grace period of 1 year to bring an application from the disclosure of a patently indistinguishable invention. ${ }^{14}$

Hearings were held before a bench of three administrative judges of BPAI (now PTAB). The process could commence either at the instance of the patent examiner or by another party. ${ }^{15}$ The aggrieved party filed a request with the patent examiner according to $37 \mathrm{CFR}$ section 41.202. The request must outline counts identifying patent claims as well as the claims which are substantially similar in the pending patent application or the unexpired patent. ${ }^{16}$

\section{Preconditions to an interference}

For a successful declaration of interference, two prerequisites must be met. First, the existence of a patentable subject matter, and secondly, that the patentable subject matters actually interfere with each other. Generally, the USPTO makes a threshold ex parte assessment of the patentability of the subject matter to satisfy the first

1135 USC s 135 (Pre-AIA).

12 Manual of Patent Examining Procedure s 2138.01(MPEP); Radio Corp of America v Radio Eng'g Labs, Inc, 293 US 1, 2, 21 USPQ 353, 3534 (1934).

13 Gerald J Mosinghoff, 'The U.S. First-To-Invent System Has Provided No Advantage to Small Entities' (2002) 84 J. Pat. \& Trademark Off. Soc'y 425.

1435 USC s 135(b) (Pre-AIA).

1535 USC s 135(a) (Pre-AIA); 37 CFR s 41.202.

$16 \quad 37$ CFR s 41.203. 
requirement. The second requirement is known as interference-in-fact.

A two-way test is employed to establish whether the subject matter of a claim of one party would, if considered prior art, have anticipated or rendered obvious the subject matter of a claim of the opposing party and vice versa. ${ }^{17}$ At this point, an interference proceeding commences.

\section{'Conception', 'reduction to practice' and 'reasonable diligence'}

Priority is established using two factors: conception and reduction to practice. ${ }^{18}$ The interference is awarded to the person who was the first to conceive the idea and reduce it to practice. ${ }^{19}$

Conception refers to 'the complete performance of the mental part of the inventive act'. ${ }^{20}$ It is established when the invention is sufficiently clear for a person skilled in the art to be able to reduce it to practice without experimentation or exercise of inventive skill. ${ }^{21}$ Reduction to practice can be either actual or constructive. ${ }^{22}$ Actual reduction to practice entails the physical manifestation of the invention. A constructive reduction refers to filing the patent application with a detailed description of how the invention would work and how to use it.

Even if the applicant was not the first to reduce to practice, she can prevail in the interference if she can show that she worked on the invention with reasonable diligence to reduce it to practice before the date of the conception of the opposing party. ${ }^{23}$

\section{'Abandonment, suppression and concealment'}

The first inventor could lose the priority contest if it can be shown that the invention was abandoned, suppressed, or concealed. ${ }^{24}$ Abandonment is measured from the date of the second inventor's conception. Failure to diligently file a patent or to describe the invention in a publicly disseminated document or to use the invention publicly has been held as abandonment, suppression or concealment. ${ }^{25}$ Therefore, once the

1737 CFR s 41.203(a); Lawrence and others, 'Interference Proceedings: When Inventions Collide' <http://www.buildingipvalue.com/n_us/137_ 141.htm > accessed 26 June 2018; See also Eli Lilly 5 \& Co $v$ Bd Regents Univ Wash, 334 F 3d 1264, 1270 (Fed Cir 2003).

1835 USC s 102(g) (Pre-AIA).

19 ibid.

20 MPEP, s 2138.04; Townsend $v$ Smith, 36 F 2d 292, 295, 4 USPQ 269, 271 (CCPA 1930).

21 Hiatt v Ziegler, 179 USPQ 757, 763 (Bd Pat Inter 1973).

22 MPEP, s 2138.05.

2335 USC s 102(g) (Pre-AIA); Keizer v Bradley, 270 F 2d 396, 399-400 (CCPA 1959).

2435 USC s 102 (g) (Pre-AIA).

25 MPEP, s 2138.03; Correge v Murphy, 705 F 2d 1326, 1330, 217 USPQ 753, 756 (Fed Cir 1983). invention has been reduced to practice, the length of time taken to file a patent might lead to an inference of concealment, suppression or concealment. ${ }^{26}$ Being the first to file the patent plays a critical role in determining inventorship. Delays can advantage the second inventor considerably in an interference proceeding.

\section{Facts of the CRISPR proceedings}

CRISPR is a bacterial immune system that responds to external attacks from viruses and plasmids. Through the combination of CRISPR and associated proteins, CRISPR-derived RNA molecules (crRNA) are able to attack and cleave the DNA of the invading virus. ${ }^{27}$ Jennifer Doudna and Emmanuelle Charpentier, along with a team of international scientists, are largely credited as the first to discover this naturally occurring system in bacteria. They published their findings in March 2012. ${ }^{28}$

There are three types of CRISPR systems: Doudna's laboratory studied the Type-II CRISPR-Cas9 system. It was found that crRNA connects via base pairs to a transactivating RNA (tracrRNA) to form a dual RNA. The RNA-guided mechanism that elegantly cleaves the DNA at the desired spot was immediately likened to a pair of scissors that could snip the DNA easily and efficiently.

The possibilities of employing this system for genome editing for plants and animals would be a huge breakthrough compared to existing technologies such as ZFNs and TALENs. ${ }^{29}$ All existing techniques required a double paired enzyme to cleave DNA; CRISPR, on the other hand, works with a single enzyme. ${ }^{30}$ Doudna and Charpentier won various awards for their discovery and eventually filed Patent Application No 13, 842, 859 on 13 March 2013, claiming a priority date of 25 May 2012. Doudna had demonstrated the use of CRISPR in an in vitro environment. The patent claims were not limited to any specific environment and seemingly extended to all uses of CRISPR. ${ }^{31}$

Meanwhile, Feng Zhang of the Broad Institute worked on developing the CRISPR system in a eukaryotic

26 MPEP, s 2138.03(I); Paulik v Rizkalla, 760 F 2d 1270, 1271, 226 USPQ 225, 226 (Fed Cir 1985).

27 See n 1; see also USPTO Interference Decision on Motions, Patent Interference No 104,048 (DK) ('USPTO Interference Decision on Motions') 2-3 generally.

28 See $n 5$.

29 Thomas Gaj and others, 'ZFN, TALEN, and CRISPR/Cas-based Methods for Genome Engineering' (2013) 31 Trends in Biotechnology 397 $<$ http://www.cell.com/trends/biotechnology/pdf/S0167-7799(13)000875.pdf $>$ accessed 26 June 2018.

30 Re patent application of Jennifer Doudna et al., Patent Appl No 13/ 842,859, 11.

31 Brief for Appellants, 14, Regents of Univ Cal v Broad Inst, Inc, No 17-1907 (Fed Cir, 25 July 2017). 
environment. Broad filed their patent application with a priority date of 12 December 2012, under a special application. Shortly afterwards, Zhang also published his findings. ${ }^{32}$ Due to the expedited procedure, Broad's application was reviewed within 6 months and the patent was granted while the one filed by UC remained pending. Broad's claim was limited to the use of CRISPR to eukaryotic cells; UC's claims were broader.

Eukaryotic cells refer to plant and animal cells. This meant that all the commercially relevant uses of CRISPR such as genetically modified crops and curing genetic diseases would actually vest in the Broad patent. UC filed its request for an interference shortly afterwards, during the prosecution of its own patent application at the USPTO.

Globally, various research laboratories and companies have been eager to jump on the CRISPR bandwagon, which seems to be promising billions of dollars as the technology is extended to genome editing and appears useful in several sectors including medicine, agriculture and industrial biotechnology. Feng Zhang was a cofounder of Editas Medicine. Editas has obtained a patent from the Broad Institute and wants to begin clinical trials soon. Jennifer Doudna, who was also a co-founder of Editas, has distanced herself from the company after the Broad patent and associated herself with Caribou BioSciences. Emmanuelle Charpentier, on the other hand, has sold her rights to CRISPR Therapeutics, yet another start-up. Most of these companies have raised large funds through Initial Public Offerings and venture capitalists. ${ }^{33}$

This turn of events eventually led to a high-stakes, winner-take-all interference between UC's patent application and Broad's patent. ${ }^{34}$ In January 2016, the interference proceeding was announced. The proceeding was concluded on 15 February 2017, when the PTAB ruled in the favor of Broad, stating there was no interferencein-fact since neither party's claims, if considered to be prior art, would render the opposing claim obvious. ${ }^{35}$ Hence, the PTAB did not invalidate any claims. Following this, UC has filed an appeal before the US Court of Appeals for the Federal Circuit, challenging the ruling. ${ }^{36}$ The appeal is pending disposal.

32 Le Cong and others, 'Multiplex Genome Engineering Using CRISPR/Cas Systems' (2013) 339 Science 819.

33 Joe Stanganelli, 'Interference: a CRISPR Patent Dispute Roadmap', BioIT World, 9 January $2017<$ http://www.bio-itworld.com/2017/1/9/interfer ence-a-crispr-patent-dispute-roadmap.aspx > accessed 26 June 2018.

34 Antonio Regalado, 'Crispr Patent Fight Now a Winner Take All match', MIT Tech Law Rev, 15 April 2015 < https://www.technologyreview.com/ s/536736/crispr-patent-fight-now-a-winner-take-all-match/> accessed 26 June 2018.

35 Broad Inst, Inc v Regents Univ Cal, No 106,048, 2017 WL 657415 (PTAB, 15 February 2017).

\section{Analysis}

The patent interference identified Broad as the junior party and The Regents of UC Berkeley along with University of Vienna and Emmanuelle Charpentier (collectively 'UC') as the senior party based on their effective filing dates. Broad was successful in showing that there was no interference-in-fact between UC's claims and its own. It argued that its claims were not rendered obvious by UC's claims when considered as prior art. ${ }^{37}$ The motion succeeded and UC lost its standing in the interference. Therefore, the interference was disposed of in the preliminary stage and no arguments were heard on the issue of priority thereon.

\section{Interference-in-fact as precondition to interference proceedings}

The PTAB exercised discretion and sought to hear Broad's motion first to decide whether the interference could be declared in the first place or not. ${ }^{38}$ The parties' respective claims were compared to determine if they interfered in fact. Reliance was placed on the two-way test outlined above and the specific points of enquiry were:

(i) Would UC's claim be rendered obvious if Broad's claim is considered prior art? and

(ii) Would Broad's claim be rendered obvious if UC's claim is considered prior art?

To declare an interference, ${ }^{39}$ the answer to both questions should be in the positive. ${ }^{40} \mathrm{UC}$ admitted that the first query should be answered in the negative. All of Broad's claims were limited to the use of CRISPR in a eukaryotic environment. This limitation was not contained in any of UC's claims which seemingly extended to all uses of CRISPR. The PTAB noted that to constitute anticipation, each limitation of a claim should be found in a single reference, either expressly or inherently. ${ }^{41}$ Therefore, Broad only had to show that, on a preponderance of evidence, ${ }^{42}$ its claims would not be rendered obvious by UC's claims if they were considered to be prior art. ${ }^{43}$

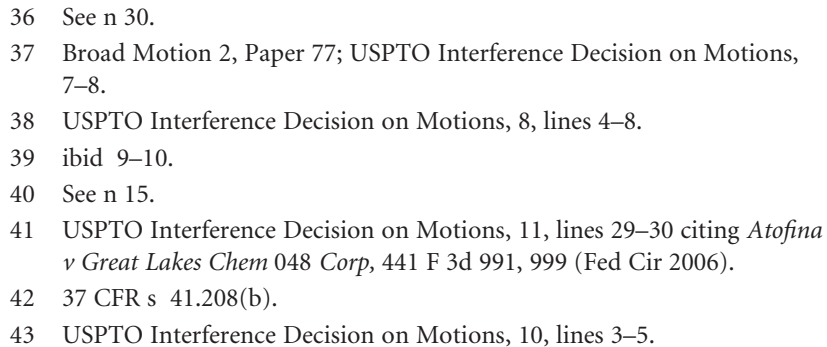




\section{Obviousness as 'reasonable expectation of success'}

The PTAB first outlined the John Deere principles as the test of obviousness. ${ }^{44}$ According to them, it is necessary to determine (i) the scope and the contours of the prior art, (ii) the differences between the prior art and the claims at issue and (iii) the level of ordinary skill in the pertinent art. ${ }^{45}$ UC's use of CRISPR in a generic environment was considered as prior art, which was compared to Broad's narrower claim in a eukaryotic cell environment. The PTAB then tried to discern the level of ordinary skill in the art by relying on Re Dow Chemical to determine obviousness. ${ }^{46}$

The test is whether the prior art would have suggested, to a person having ordinary skill in the art, that this process should be carried out and would have a reasonable likelihood of success. ${ }^{47}$ Doudna's and Charpentier's 2012 article demonstrated the use of CRISPR in vitro and discovered its presence in prokaryotic cells. The entire interference hinged on ascertaining whether UC's claim of using CRISPR in a generic environment would have led to a reasonable expectation of success in using CRISPR in an eukaryotic environment.

\section{Conflicting contemporaneous statements undermine reasonable expectation of success}

Broad argued that, even though CRISPR was shown to work in prokaryotic environment, those skilled in the art did not believe that it would also work in eukaryotic cells, as claimed in their patent application. ${ }^{48}$ Broad pointed out that Doudna herself questioned the ease of applying CRISPR to eukaryotic cells. Various statements were quoted to explain that she was 'unsure if CRISPR-Cas9 would work in eukaryotes' and that she had experienced 'many frustrations'. She had stated that the modifications required making these technologies work in animals and humans had been 'a huge bottleneck in human therapeutics'. ${ }^{49}$ UC argued that these statements should be taken to mean that the use of CRISPR in eukaryotes was clearly foreseeable and only experimental demonstration was left.

Agreeing with Broad, the PTAB held that, while there could be an eagerness to learn the results of experiments in eukaryotic cells, an expectation that the

\footnotetext{
44 ibid 12, lines 10-12.

45 Graham v John Deere Co Kansas City, 383 US 1, 17 (1966).

46 USPTO Interference Decision on Motions, 12, lines 18-21.

47 Re Dow Chemical Co, 837 F 2d 469, 473 (Fed Cir 1988).

48 USPTO Interference Decision on Motions, 13, lines 7-10.

49 ibid 15.

50 ibid 17, lines 14-16.

51 ibid 4, lines 14-16.
}

results would be successful was undermined by Doudna's statements. If the inventors were unsure, persons of ordinary skill would surely not reasonably expect any success. ${ }^{50}$

UC presented Dr Dana Carroll of the University of Utah, and Dr Carol Greider of the John Hopkins University School of Medicine as expert witnesses. ${ }^{51} \mathrm{Dr}$ Carroll's testimony attempted to demonstrate how the use of CRISPR in eukaryotes could be reasonably expected. Established methods such as codon optimization, manipulations of ions and $\mathrm{pH}$ made it foreseeable that CRISPR could be successfully modified for a eukaryotic environment. However, the testimony was discounted by contemporaneous statements made by Dr Carroll himself at the time Jinek 2012 was published. He expressed his doubt stating that, 'there is no guarantee that Cas9 will work effectively on a chromatin target or that the required DNA-RNA hybrid can be stabilized in that context'. ${ }^{52}$ The PTAB observed that contemporaneous evidence is to be given more weight, as testimony is specifically prepared for the proceedings. ${ }^{53}$

UC presented other contemporaneous evidence and commentaries that allegedly suggested it was immediately obvious' to use the system for genome engineering. ${ }^{54}$ CRISPR's comparison to ZFNs and TALENs indicated that it could be employed in eukaryotes. The PTAB, however, disagreed. It held that these statements were positive and forward-looking, but only indicated a 'possibility' or 'potential' and did not translate to an expectation of success. ${ }^{55}$

UC's case was considerably weakened by conflicting statements contemporaneously made by Dr Doudna, the inventor and Dr Carroll, the expert witness. This may lay down an undesirable standard for scientists where they may be incentivized to be dishonest about their scientific research. ${ }^{56}$

\section{Wide-scale experimentation in eukaryotes does not evidence 'reasonable expectation of success'}

UC argued that the large number of scientific groups who were able to employ CRISPR in eukaryotic cells immediately after the publication of Jinek 2012, should be taken as evidence of a reasonable expectation of

52 ibid 19, lines 15-17.

53 ibid 14; See also Cucuras $v$ Sec'y of Dep't of Health \& Human Servs, 993 F 2d 1525, 1528 (Fed Cir 1993).

54 ibid 21-22.

55 ibid 22, lines 17-19.

56 Sharon Begley, 'The CRISPR Patent Decision: Your Six Takeaways', Stat+, 16 February 2017 <https://www.statnews.com/2017/02/16/crisprpatent-decision-six-takeaways/> accessed 26 June 2018. 
success. ${ }^{57}$ The PTAB distinguished motivation from a reasonable expectation of success by opining that the eager movement towards this direction does not necessarily mean that the experiments were being carried out with a reasonable expectation of success. ${ }^{58}$ A scientist's 'belief' in the success of his/her own experiment does not necessarily mean that there was a reasonable expectation of success indicating obviousness. If this 'belief' was sufficient, the requirement of 'reasonable expectation of success' would be rendered meaningless.

\section{Reasonable expectation of success for scientific experiments to be assessed on a case-by-case basis}

The PTAB referred to the Federal Court decision in Abbott Labs $v$ Sandoz, Inc, 544 F 3d 1341, 1352 (Fed Cir 2008) which held that, in the case of scientific experiments, instead of employing a presumption of obviousness, the case must be decided in its particular context. $^{59}$ The evidence in this case was compared to the facts of several precedential cases, ${ }^{60}$ and it was concluded that obviousness depended heavily on what was known from the prior art of closely related subject matter. Availability of specific instructions or success in similar methods or products usually led to a finding of reasonable expectation of success. Only generalized instructions and evidence of failure with similar subject matter have indicated the opposite. ${ }^{61}$

Accordingly, the PTAB assessed if there were instructions in prior art specifically relevant to CRISPR that would instruct those of ordinary skill to use the technique in eukaryotic cells. They also assessed if there were examples in prior art of the success or failure of similar systems.

According to Broad's expert witness, ordinarily skilled scientists knew of various differences in prokaryotic and eukaryotic cells that would hinder the use of CRISPR in eukaryotic cells. More specifically, the tightly packed DNA in eukaryotic cells would pose a challenge as compared to the naked plasmid DNA used in Jinek 2012. ${ }^{62}$ Dr Simons additionally argued that protein folding in eukaryotes would also pose challenges as misfolded proteins in eukaryotes are degraded in a manner unlike prokaryotes. ${ }^{63} \mathrm{UC}$ argued that these differences would not be impediments.

In the cross-examination, Dr Simons admitted that none of the challenges identified by him were actually faced by the Broad Institute. The PTAB did not consider this relevant as the question before them was whether scientists would have expected to face these challenges and not if they actually faced them. ${ }^{64}$

UC opposed Dr Simons' claims by relying on its own witnesses, Dr Greider and Dr Carroll. According to them, protein folding would not be an expected impediment, as other prokaryotic proteins were known to fold properly. It was also well known that functional proteins could be injected directly into eukaryotic cells. They addressed concerns raised against a tightly packed DNA in eukaryotes and pointed out that various methods, such as codon optimization and $\mathrm{pH}$ balancing, were available to tackle the differences between a prokaryotic and eukaryotic environment. ${ }^{65}$

The PTAB once again pointed to Dr Carroll's contemporaneous statements, which questioned whether 'Cas9 could effectively work on a chromatic target'. ${ }^{66}$ It decided that Broad's arguments were on a balance more compelling and that success with select prokaryotic proteins would not have provided those of ordinary skill with a reasonable expectation that CRISPR would work in an eukaryotic chromatin. ${ }^{67}$

Broad also presented several examples of failed attempts to transfer other prokaryotic RNS-based systems to eukaryotic environments, ${ }^{68}$ while UC argued that Dr Simon's testimony itself showed that all these systems would eventually work in an eukaryotic environment. ${ }^{69}$ The PTAB noted that all the systems pointed out by Broad required a unique set of conditions specifically tailored to the particular system. UC did not draw any commonality between these conditions and those that can be applied to CRISPR. It appeared CRISPR would also require its own specific set of conditions. ${ }^{70} \mathrm{UC}$ and the Broad disagreed over various scientific questions, including the characterization of other gene editing technologies such as ZFNs and TALENs. Overall, the PTAB could not find any specific instructions relevant to CRISPR to allow its implementation in a eukaryotic environment. It was persuaded that the failures of other systems would have contributed to a lack of a reasonable expectation of success.
57 USPTO Interference Decision on Motions, 23, lines 7-9 .

58 ibid 23, lines 15-18; 24, lines 13-16.

59 ibid 25, lines 24-25.

60 ibid 26, line 1.

61 ibid 28.

62 ibid 30.

63 ibid 29-31.

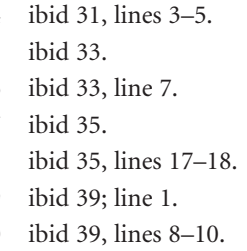




\section{Reliance on third-party provisional applications as prior art is not permissible}

Finally, UC attempted to rely on another provisional application (Kim provisional) and its own applications to prove that Broad's application was rendered obvious. The Kim provisional claimed the possibility of using the CRISPR taught in Jinek 2012 for genome editing in cells and organisms. ${ }^{71}$ UC argued that, as the Kim provisional had been filed prior to Broad's patent application, it would constitute prior art and render Broad's claim obvious. However, the PTAB decided that this was a question of patentability not of interference-in-fact. Further, the Kim provisional and other applications were not informative because the contents of those applications were not public. Prior art other than the party's claims can be considered only to decide what those of ordinary skill knew at the time. $^{72}$

The PTAB concluded that, on a preponderance of evidence, Broad had succeeded in showing that there was no interference-in-fact. Accordingly, UC was deprived of any standing to bring any other challenges to Broad in the interference. No judgment was entered against either party's claims.

\section{Practical significance}

The PTAB ruling provides guidance on the concept of obviousness in biotechnology patents. Once the basics of a technique are well known-does the application of the technology in different contexts become obvious? ${ }^{73}$ This decision unequivocally answers the question in the negative. The query hinged mostly on the reasonable expectation of success in using the technology in a different context.

The appeal before the US Court of Appeals for the Federal Circuit may delve into those possibilities. $^{74}$ Uncertainty in this regard may stall the commercialization of the technology for significant time. ${ }^{75}$ The entire patent dispute may even be rendered redundant with

71 ibid 46, lines 15-17.

72 ibid 48 , lines $1-2$.

73 Jacob S Sherkow, 'Law, History and Lessons in the CRISPR Patent Conflict' (2015) 33 Nat Biotechnol 256.

74 See $n 34$.

75 Heidi Ledford, 'Broad Institute Wins Bitter Battle over CRISPR Patents' Nature, 15 February 2017 <http://www.nature.com/news/broad-insti tute-wins-bitter-battle-over-crispr-patents-1.21502> accessed 26 June 2018.

76 Sarah Buhr, 'Scientists Have Eliminated HIV in Mice using CRISPR' TechCrunch, 4 May 2017 <https://techcrunch.com/2017/05/03/scien tists-have-eliminated-hiv-in-mice-using-crispr/> accessed 26 June 2018.

77 See $n 54$. swift technological advances in the field. ${ }^{76}$ If a more commercially viable solution is made available any time soon, the dispute between Broad and UC might ultimately be of very little importance. ${ }^{77}$

At a practical level, it is unclear which patent allows use of the technique. UC's patents are broadly worded while Broad's patents are limited to use in eukaryotic cells. In Doudna's words, 'they have the patent to all green tennis balls while we have the patent to all tennis balls'. ${ }^{78}$ This means that companies might need to obtain a licence from both patentees to avoid liability. ${ }^{79}$ Despite the interference proceeding, it also remains unclear whether UC's patent would cover all uses of CRISPR. This could drive up the cost of commercialization. An elegant solution would be a settlement between the two patentees: indeed, many have expressed their surprise that a settlement has not yet been reached. ${ }^{80} \mathrm{~A}$ USPTO Communication acknowledges the possibility of more challenges, including additional interferences by other CRISPR-centric biotech companies. ${ }^{81}$

Prior to the transition to the first-inventor-to-file system in the USA, the long and expensive process of interference was suspected to often lead to abandonment of patent applications altogether. The prohibitive cost of having to prove the date of conception prevented several small or independent inventors from claiming inventorship. Thus, in such instances, the second to conceive could often succeed in their claim. In that regard, AIA caters to the interests of such inventors and allows for greater certainty in determining inventorship in a less cumbersome manner.

AIA has sought to eliminate principles such as 'conception of invention' and 'reduction to practice', which characterize the 'first to invent notion'. However, it was clarified by the former USPTO Director that there are systemic checks to protect the interests of the first inventor: ' $t$ ] here is no risk of someone who learns about your invention being able to beat you to the patent office; because they're not an inventor. As you know, any filer has to sign an oath and declaration under penalty of criminal sanctions. ${ }^{82}$

78 See Doudna's interview at: Sarah Buhr, 'CRISPR-Cas9 Inventor Jennifer Doudna's Plans on Moving Forward, Genetically Modifying Humans', TechCrunch, 15 February 2017 <https://techcrunch.com/2017/02/15/ crispr-cas9-inventor-jennifer-doudnas-plans-on-moving-forward-geneti cally-modifying-humans/> accessed 26 June 2018.

79 See $n 75$.

80 Sarah Zhang, 'How the CRISPR Dispute Became So Heated', The Atlantic, 6 December 2016 <https://www.theatlantic.com/science/ar chive/2016/12/crispr-patent-in-court/509579/> accessed 26 June 2018.

81 Office Communication in US Patent Application No 15/435, 233, 15 December 2017.

82 David Kappos, 'Director's Forum: A Blog From Uspto's Leadership', 10 November $2009<$ https://www.uspto.gov/blog/director/entry/director_s forum_david_kappos $>$ accessed 26 June 2018. 
The new system under AIA aimed at simplifying the procedural hurdles in proving inventorship. The yearlong grace period to file a thorough application accompanied by a greater breadth of disclosure, including the best mode to practice the invention, is encouraging. Inventors can file for the patent after making a complete public disclosure of the invention in any way or may even conduct the first sale prior to filing, which is expected to result in better quality patent applications, fewer post-grant invalidations and improved patent commercialization practices.

As a matter of law, post-AIA any US inventor who has priorly published information regarding their invention cannot be denied a patent due to another that has obtained or derived a subsequent disclosure from such publication. In this dispute, Broad is allegedly the 'deriving party' that has presented sufficient evidence to disprove the allegation raised by UC at the first instance. The reform introduced by AIA actually enhances the requirement for this evidence that authenticates who is the true inventor by seeking to corroborate inventorship, producing proof regarding conception of the invention and reducing it to actual or constructive practice by filing the patent application. Lack of evidence causes the date of filing the application to be noted as the only date of invention. Also, 'derivation proceedings' are only concerned with the person who filed first, whether or not she is the inventor. Once the required affidavitory evidence of authorization is presented, the priority stands. It is an extension of the inter partes and post-grant review processes. Thus, if the CRISPR-Cas9 dispute had arisen post-AIA, the ruling may have favoured UC on account of the date of filing. However, such determination would not include the interpretation of the broadly worded claims or their possible negative impact on innovation. Procedurally, the case is a better fit for a pre-AIA priority contest.

83 See $\mathrm{n} 73$.

8442 USC s 262 (i) (1); See also Zachary Brennan, 'Regulating CRISPR: FDA and Industry Offer Perspective', Reg Aff Profs Soc'y, 21 June $2017<$ https:// www.raps.org/regulatory-focus\%E2\%84\%A2/news-articles/2017/6/regulatingcrispr-fda-and-industry-offer-perspective $>$ accessed 26 June 2018. FDA, 'What is Gene Therapy', 9 January $2018<$ https://www.fda.gov/ BiologicsBloodVaccines/\%20CellularGeneTherapyProducts/\%20ucm573960. htm $>$ accessed 26 June 2018.

85 Maryann P. Feldman and others, 'Lessons from the Commercialisation of the Cohen-Boyer Patents: The Stanford University Licensing Program' in A. Krattiger and others (eds), Intellectual Property Management in Health and Agricultural Innovation: A Handbook of Best Practices (MIHR: Oxford, UK, and PIPRA: Davis, 2007). <http://www.iphand book.org/handbook/ch17/p22/> accessed 26 June 2018.

\section{CRISPR technology patents: suggestions for a way forward}

Broadly worded patents can create serious market inefficiencies. ${ }^{83}$ Currently, market exclusivities and approvals, as well as compliances for treatments concerning CRISPR-Cas9 technologies, are governed by the Biologics Price Competition and Innovation Act, 2009 (BPCIA) ${ }^{84}$ However, broadly worded patents would result in very restrictive licensing of the patent so much so that even academic research may be prohibited in addition to impeding scientific progress. Though this might be entirely speculative, given the rapid progress with CRISPR, Sherkow suggests to look at other parallels and examples of innovation in biotechnology to evolve fair practices for transferring technology.

Stanford's management of the Cohen-Boyer patent provides a helpful example. The University granted non-exclusive licences, allowing non-profits to use the research tools without a licence, and provided a staggered royalty framework to ensure that small businesses are not unfairly affected. ${ }^{85}$ Similarly, one of MIT's 'Tuschl patents' can be used by scientists for free and companies are granted non-exclusive licences for most types of commercial research. ${ }^{86}$ If ongoing discussions on creating a worldwide CRISPR-Cas9 licensing pool succeed, the actual impact on innovation will be witnessed and possibly even measured as a gold standard. ${ }^{87}$ Hence, the effect that pooling would have on such an arrangement will need close and careful study to be considered a worthwhile parallel measure. The polymerase chain reaction patents provide another unique example, where a system of 'rational forbearance' was followed and scientists refrained from suing each other for research. ${ }^{88}$ A similar approach can be used for CRISPR patents, to make sure that overly restrictive licensing does not stall scientific research in the long run, but proves to be a win-win for all concerned.
86 See $\mathrm{n} 73$.

87 Broad Institute, 'The Broad Institute of MIT and Harvard Joins Discussions to Create World-Wide CRISPR-Cas9 Licensing Pool', 10 July 2017 < https://www.broadinstitute.org/news/broad-institute-mit-and-har vard-joins-discussions-create-worldwide-crispr-cas9-licensing-pool> accessed 26 June 2018.

88 Joe Fore and others, 'The Effects of Business Practices, Licensing, and Intellectual Property on Development and Dissemination of the Polymerase Chain Reaction: Case Study' (2006) 1 J. Biomed Discov Collab $7<$ https://www.ncbi.nlm.nih.gov/pubmed/16817955> accessed 26 June 2018. 